\title{
Measuring time and money to improve patient outcomes
}

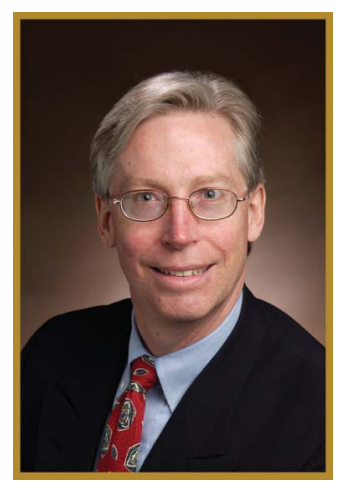

he morbidity and mortality associated with stroke continue to be staggering. Important strides have been made toward educating the public about the signs

of stroke. First responders, neurohospitalists, and hospital administrators have begun to work in concert to minimize door-to-needle time to enhance the likelihood of a favorable outcome (current guideline is less than 60 minutes, but fewer are better).

This issue of Neurology ${ }^{\circledR}$ Clinical Practice features a series of articles curated by José Merino focusing on the importance of timely evaluation, decision-making, and treatment of stroke and neurovascular disease. Featured articles explore diagnosing cryptogenic stroke (Yaghi and Elkind, p. 386) and managing blood pressure in stroke (Bowry et al., p. 419). Tai et al. (p. 427) discuss opportunities for redesigning stroke care to maintain quality and lower costs.

Companion articles in our Eye on Practice section discuss the growing impetus to maintain quality standards and measurements. Cheng et al. (p. 441) acknowledge that health care is shifting from a volume-based to value-based reimbursement paradigm and offer a foundation for analyzing current and future quality measurement programs. Wang et al. (p. 447) offer practical steps with specific examples to assist in incorporating quality measures into a neurology practice.

Up-to-the-minute comments are now available online in our correspondence section, The Nerve! Readers Speak. We urge readers to share their opinions and keep up with their colleagues' discussions on NCP's articles. Submit comments online by clicking on the "Respond" button in the right column of the full-text online version of an article with the expectation that the comment, if accepted, will be posted quickly, generally within 5 business days.
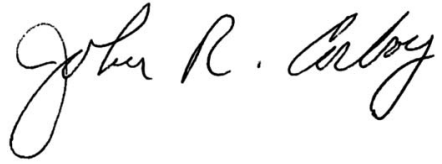

John R. Corboy, MD, FAAN 


\title{
Neurology ${ }^{\circ}$ Clinical Practice
}

\author{
Measuring time and money to improve patient outcomes \\ Neurol Clin Pract 2014;4;369 \\ DOI 10.1212/CPJ.0000000000000083
}

This information is current as of October 13, 2014

\section{Updated Information \& Services}

Permissions \& Licensing

Reprints including high resolution figures, can be found at:

http://cp.neurology.org/content/4/5/369.full.html

Information about reproducing this article in parts (figures,tables) or in its entirety can be found online at:

http://cp.neurology.org/misc/about.xhtml\#permissions

Information about ordering reprints can be found online: http://cp.neurology.org/misc/addir.xhtml\#reprintsus

Neurol Clin Pract is an official journal of the American Academy of Neurology. Published continuously since 2011, it is now a bimonthly with 6 issues per year. Copyright ( 2014 American Academy of Neurology. All rights reserved. Print ISSN: 2163-0402. Online ISSN: 2163-0933.

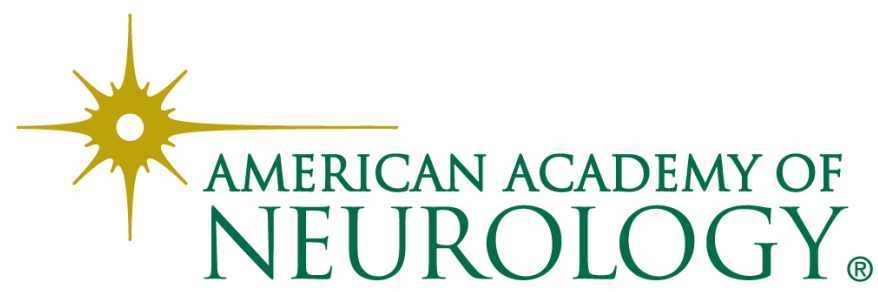

